\title{
TITLE:
}

\section{ON SOME FUNGI ISOLATED FROM THE ANTARCTIC MATERIALS}

\author{
$\operatorname{AUTHOR}(\mathrm{S})$ : \\ Tubaki, Keisuke
}

CITATION:

Tubaki, Keisuke. ON SOME FUNGI ISOLATED FROM THE ANTARCTIC MATERIALS. SPECIAL PUBLICATIONS FROM THE SETO MARINE BIOLOGICAL LABORATORY 1961, 1(14): 1-9

\section{ISSUE DATE:}

1961-03

URL:

http://hdl.handle.net/2433/176444

RIGHT: 
SPECIAL PUBLICATIONS FROM THE SETO MARINE BIOLOGICAL LABORATORY

BIOLOGICAL RESULTS

OF

THE JAPANESE ANTARCTIC RESEARCH EXPEDITION

14.

\section{ON SOME FUNGI ISOLATED FROM THE ANTARCTIC MATERIALS}

BY

\section{KEISUKE TUBAKI}

NAGAO INSTITUTE

380, MISHUKU, SETAGAYA-KU, TOKYO

SIRAHAMA, WAKAYAMA-KEN

JAPAN

MARCH 1961 
SPECIAL PUBLICATIONS FROM THE SETO MARINE BIOLOGICAL LABORATORY

BIOLOGICAL RESULTS

$\mathrm{OF}$

THE JAPANESE ANTARCTIC RESEARCH EXPEDITION

14.

\section{ON SOME FUNGI ISOLATED FROM THE ANTARCTIC MATERIALS}

BY

\section{KEISUKE TUBAKI}

NAGAO INSTITUTE
380, MISHUKU, SETAGAYA-KU, TOKYO

Part of the work was reported on the

Sympodium on the Antarctic, June 1, 1960.

SIRAHAMA, WAKAYAMA-KEN

J A P A N

MARCH 1961 
This series contains THE BIOLOGICAL RESULTS OF THE JAPANESE ANTARCTIC RESEARCH EXPEDITION and is published by the Seto Marine Biological Laboratory. Parts will appear at irregular intervals as they become ready. 
THE fungi described in this paper are based on the materials of the Antarctic collections made by the members of the Japanese Antarctic Research Expedition at Showa Base during the year of 1959 and 1960. I have had the opportunities of the isolation of these fungi under pure culture from those of nearly 50 materials which forwarded to me through Dr. H. Funushima, Yokohama Municipal University. The collections were made at the following four places: West Ongul Island, East Ongul Island, Showa Base and the continent.

After these materials, mostly soily, were picked up into the polyethylene sacks or bottles, they had been maintained in the refrigerator-room of the SÔYA, then brought to my laboratory. Immediately after their arrival to the laboratory, direct isolation on agar was tried as the main method for the cultivation of these Antarctic fungi. For the isolation, malt agar was used mostly which was adjusted at $\mathrm{pH} 3.4-3.5$ for preventing the bacterial growth. Cultivation was carried out at $15^{\circ}, 20^{\circ}$ and $25^{\circ} \mathrm{C}$.

At present, 19 strains of fungi have been isolated from 48 materials. They were distributed into 4 species and described in this paper. From those of 25 , no fungi and yeasts had appeared.

Detailed data of fungi are summarised in the following Table 1.

Table 1.

\begin{tabular}{|c|c|c|c|c|}
\hline Localities & Date & $\begin{array}{l}\text { Number of } \\
\text { strains }\end{array}$ & $\begin{array}{l}\text { Number of } \\
\text { species }\end{array}$ & $*$ \\
\hline $\begin{array}{l}26 \text { soily materials of } \\
\text { East \& West Ongul Isl. }\end{array}$ & $\begin{array}{l}\text { The 3rd J.A.R.E. } 1959 \\
\text { (H. FUKUSHIMA) }\end{array}$ & 5 & 5 & 15 \\
\hline $\begin{array}{l}18 \text { soily materials of } \\
\text { East \& West Ongul Isl. }\end{array}$ & $\begin{array}{l}\text { The } 4 \text { th J.A.R.E. } 1960 \\
\text { (T. MATSUDA \& } \\
\text { R. HAGA) }\end{array}$ & 12 & 5 & 7 \\
\hline $\begin{array}{l}4 \text { soily materials of the } \\
\text { continent }\end{array}$ & $"$ & 2 & 2 & 3 \\
\hline
\end{tabular}

* Number of materials from which no fungi and yeasts appeared.

Fungi determined are summarised in the next Table 2.

Table 2.

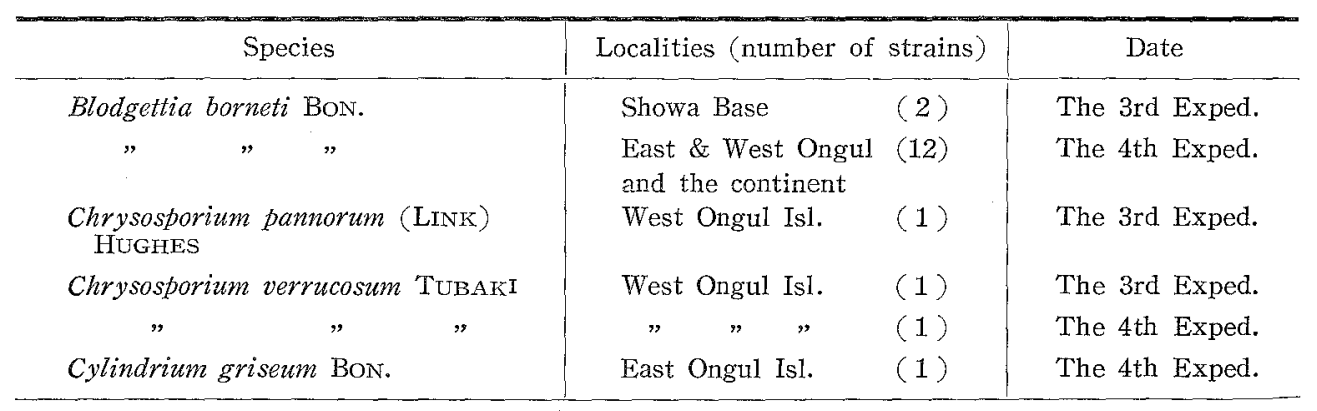




\section{SPECIES EXAMINED}

1. Blodgettia borneti WRIGHT, in Trans. Irish Acad. $28: 25$ (1881);

SACCARDO, Syll. Fung. 10:664 (1892)

Growth rather slow, effuse, wooly, olive-brown to olive-green colored, reverse dark olive to almost black. Hyphae septate, branched repeatedly, $5(6) \mu$ or more in diam., pale olive to subhyaline. Conidiophore not well differentiated,

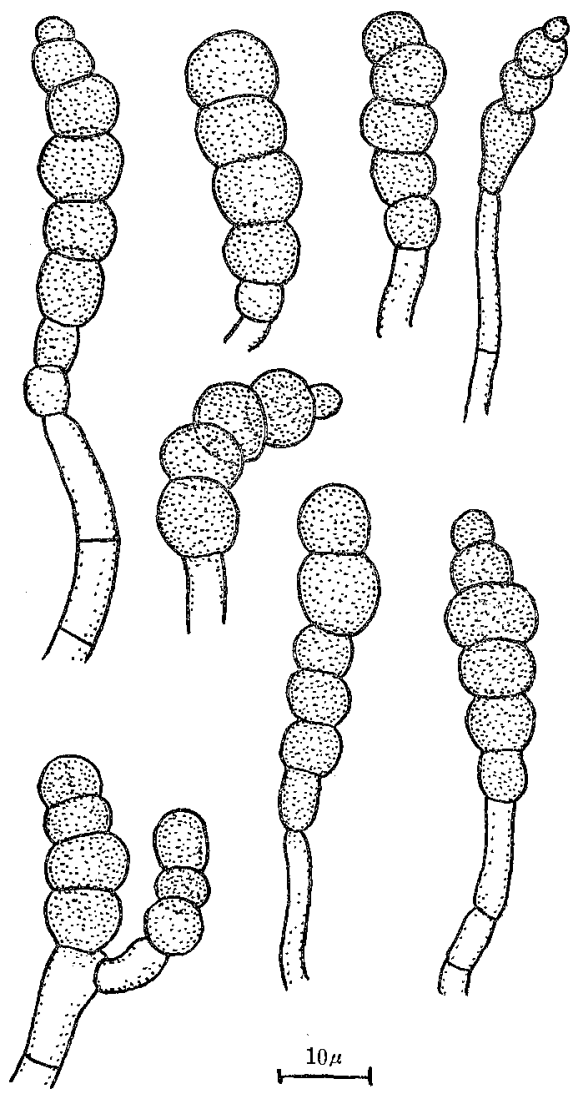

Fig. 1. Blodgettia borneti WRIGHT.

of variable length, septate, often constricted at the septa, $4-5 \mu$ in diam. No conidia developed under such cultural conditions on malt agar, potato agar and Czapek agar. Growth on PHB-agar (p-hydroxy benzoic acid 0.1\%), very slow and restrict; conidia developed fairly abundant at the center of the colony under this condition; conidia also developed under culture on $0.1 \%$ glucoseCzapek agar and plain agar. Conidia acrogenous or intercalar on not well differentiated conidiophore, thick-walled, torulose, 4-7 (8)-septate, markedly 
On some fungi isolated from the Antarctic materials

constricted at the septa, the middle cells larger and broader, basal and apical cells progressively narrower, the basal cell mostly doliform, $25-45 \mu$ long and $9-10 \mu$ width at the broadest parts, dark colored.

Hab. From 13 soil-samples, East and West Ongul Isl., and the continent, collected by H. FukUSHIMA (1959) and T. MATSUDA \& R. HAGA (1960); algal material, water pool in Showa Base, collected by H. FuKusHrma (1959).

I treat this species with deep interest because this species was originally described by WRIGHT (1881) as algicolous on Cladophora caespitosa. In addition to one of the present strains which was isolated from the algal materials as noted above, a same fungus has developed inside of the test-tube during the isolation of the Antarctic algae using Detmer's media. Moreover, I have found a same fungus from the inside of the mosseous material which was collected by the 1st J.A.R.E. (1957). The physiological relationships between the present species and the algae may be considerable.

In 1954, Subramanian established a second species, Blod. indica Sub. which was found on the dead stubble submerged in water. It differs from the present species in the acrogenous formation of single conidia at the tip of conidiophore. However, conidia of my fungus are not only acrogenous but intercalar and the apical cell of the conidia is round differing from that of SuBRAMANIAN's species which is triangulate.

Though undue importance should not be attached to the habitat in delimiting species, in general characteristics, it comes closest to B. borneti WRIGHT in spite of the meagre original description. At present, therefore, $I$ have assigned my fungus to the above species though comparative study between the type culture of this species and the present strain is impossible.

\section{Chrysosporium pannorum (LINK) HUGHEs, in Canad. Jour.}

Bot. $36: 749$ (1958)

syn. Aleurisma carnis (Brooks et Hansf.) BISBy.

Sporotrichum carnis BroOKS et HANSFORD.

Growth rapid, more or less restricted, colony powdery, closely appressed to the agar, pure white at first, then becoming pale yellow, brownish yellow and dark gray-brown color, reverse orange-yellow when matured; hyphae creeping, interwoven, branched irregularly, obscurely septate, sinuous, hyaline, $2-3 \mu$ in diam. Conidiophore not well differentiated, straight or branched verticillately or irregularly, bearing single conidium terminally by cutting-off from the end branch of the conidiophore, $1.5-2 \mu$ in diam., hyaline. Conidia are of the aleuriospore-type, terminally, attached by the full width of the branch, ovate to pear-shaped, smooth-walled, $2-5 \times 2-3.5(4) / k$, hyaline or pale cream.

Hab. Soil, West Ongul Isl., collected by $\mathbb{H}$. Furushima, 1959.

This species has been known to grow well at lower temperature and to 


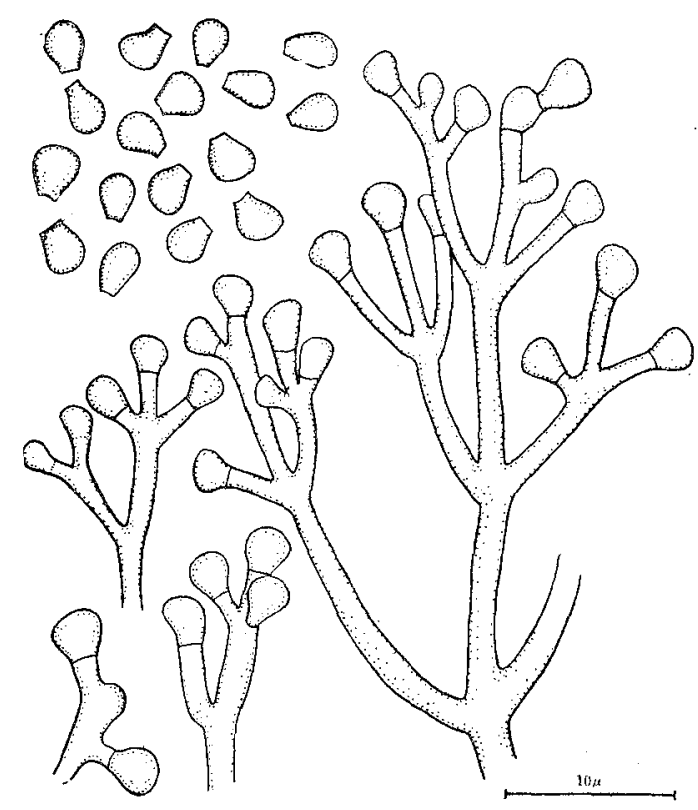

Fig. 2. Chrysosporium pannorum (LINK) HuGHES.

infects meat in cold storage at temperature as low as $-6^{\circ} \mathrm{C}$. In the present study, it also grows at lower-temperature as shown in Table 3.

\section{Chrysosporium verrucosum TUBAKI sp. nov.}

Cultura rapide incrassata, effusa, primo alba, deinde pallide cinereo-olivacea, reverso brunnea. Conidiophora e hyphis aerialibus lateraliter, irregulariter ramosa, $2.5-3 \mu$ crassa. Conidia e terminale conidiophori, ovoideae vel pyriformia, verrucosa, $3.5-5 \times 2.8-3 \mu$.

Growth fairly rapid, effuse, colony velutinous, at first white, then becoming pale grayish green with pinkish tint, reverse light brown to dark brown colored. Conidiophores not well differentiated, solitary, arising as lateral branches from aerial hyphae, branched irregularly, laterally or often verticillately, bearing single conidium terminally by cutting-off from the end branch, $2.5-3 \mu$ in diam., hyaline. Conidia are of the aleuriospore-type, terminally, attached by the full width of the branch, ovate or pear-shaped, verrucose, $3.5-5 \times 2.8-3 \mu$, hyaline or pale colored. Often the conidia may produce germ-tubes, but still attached to the branch, on which next conidia borne.

Hab. Soil, the highest point of West Ongul Isl., collected by R. HAGA, 1960.

Type culture is preserved in Nagao Institute.

This species clearly differs from other known species of Chrysosporium in the verrucose and larger conidia. Ch. pannorum (LINK) HuGHES fairly approaches 
On some fungi isolated from the Antarctic materials

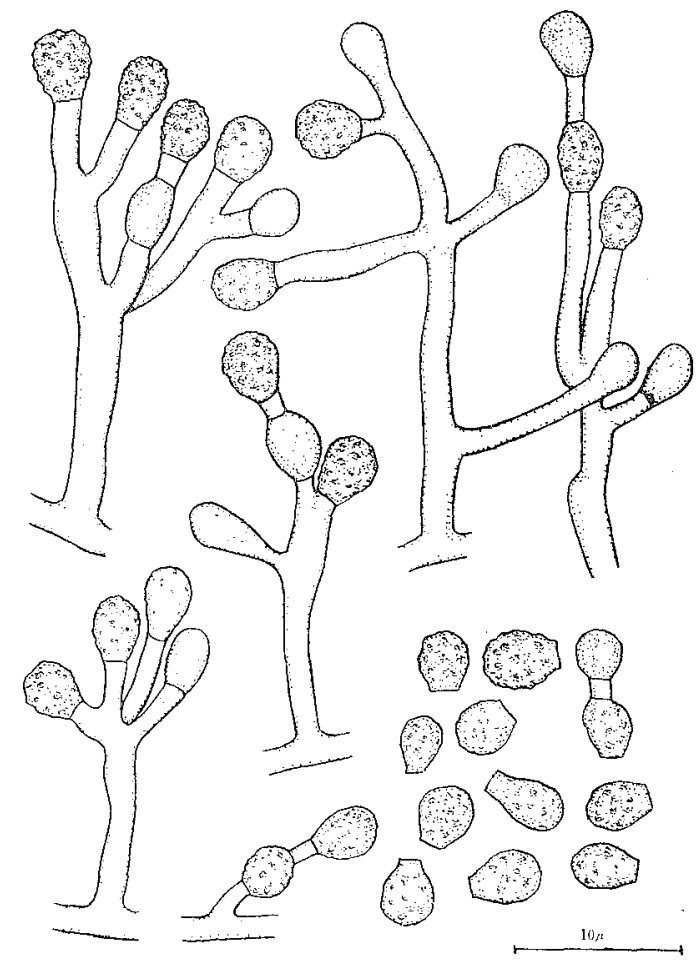

Fig. 3. Chrysosporium verrucosum TUBAKI, sp. nov.

to the present fungus and, by the personal communication of Dr. J. W. CARMICHAEL, University of Alberta, its colony varies greatly in color, but the wall of the conidia is smooth, differing from that of the present fungus.

4. Cylindrium griseum BonorD., Abhandl. $\mathbb{1}: 88$ (1864);

SACCARDO, Syll. Fung. 4:37 (1886)

Growth fairly rapid, restrict, colony composed of velutinous mycelium, with broad marginal hyphae, raised at central area, gray-green to olive-green colored, reverse dark olive to almost black. Aerial hyphae sinuous, branched irregularly, septate, $1.7-2.5 \mu$ in diam., with fairly rich anastomosis, pale olive colored. Conidiophore not well differentiated from the hyphae; whole hyphae consist of a slender, branched or unbranched mycelium which breaks up into long, cylindrical conidia. Conidia catenulate, long cylindrical, abruptly rounded at both ends, $12-17(23) \times 1.0-1.5(2) \mu$, hyaline or pale olive colored.

Hab. Soil, East Ongul Isl., collected by T. Matsuda, 1960.

This species also approaches to C. aeruginosum (LINK) RABENHORST in general appearance, but differs from it in the length of conidia. 


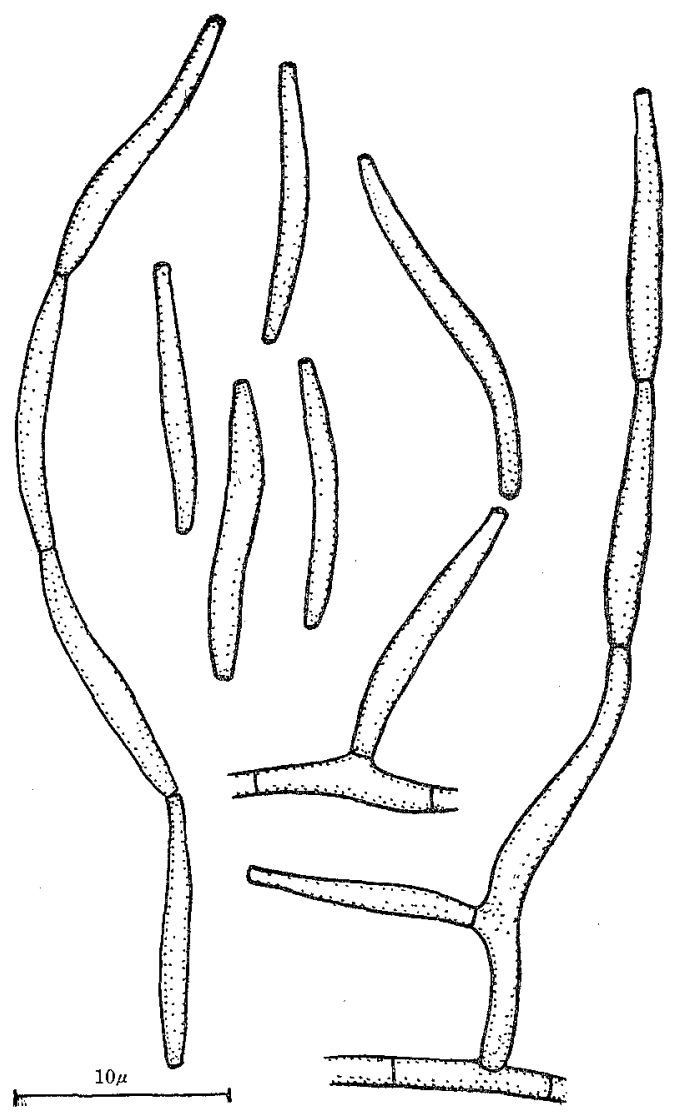

Fig. 4. Cylindrium griseum Bonord.

\section{EFFECT OF TEMPERATURE FOR THE GROWTH}

As to know the optimum temperature for the growth, the above four species were maintained at each $5^{\circ}, 12^{\circ}, 20^{\circ}, 25^{\circ}$ and $30^{\circ} \mathrm{C}$ for nearly two weeks. The results are shown in Table 3 .

As shown in the table, all species can take growth at even $5^{\circ} \mathrm{C}$ and can not grow at $30^{\circ} \mathrm{C}$. In addition to the above table, it is noticeable that both

Table 3. Temperature range of the growth.

\begin{tabular}{|c|c|c|c|c|c|}
\hline $\begin{array}{ll} & \text { Temp. } \\
\text { Species }\end{array}$ & $5^{\circ} \mathrm{C}$ & $12^{\circ} \mathrm{C}$ & $20^{\circ} \mathrm{C}$ & $25^{\circ} \mathrm{C}$ & $30^{\circ} \mathrm{C}$ \\
\hline Blod. borneti & + & + & $H+$ & H & - \\
\hline Ch. pannorum & H & H & tit & $H$ & - \\
\hline Ch. verrucosum & + & + & Hit & + & - \\
\hline Clind. griseum & + & + & H & H & - \\
\hline
\end{tabular}


On some fungi isolated from the Antarctic materials

of Chrysosporium pannorum and Blodgettia borneti showed fairly marked growth below $0^{\circ} \mathrm{C}$ in the refrigerator after one month; especially, the former species can grow very markedly under this lower temperative condition.

In general, the character of low-temperative growth, though it is slow, will be more significant one for the Antarctic fungi than that of fine growth at optimum temperature.

\section{CONCLUSION}

Though the information on fungi collected from the Antarctic continent and its surrounding islands can not be found as far as I know, it is fairly agreeable to guess the existence of fungi on there after the treating of such Antarctic organisms as algae, mosses or lichen, hitherto collected by the members of J.A.R.E. However, it is impossible to discuss throughly the microflora of the Antarctic, because the number of fungi examined is very few. Actually, it is difficult at present to bring the Antarctic materials to the laboratory under the natural condition. Therefore, the present author makes only the descriptions of species in this paper.

As described above, the technique of the isolation of Antarctic fungi is very difficult and it is impossible to decide whether they are truly Antarctic or not. But, at present, the fungi collected can be divided theoritically into the following four categories.

1) The Antarctic fungi; standing members in the antarctic.

2) Fungi carried in the Antarctic from other places during the research and contaminated the materials when collected.

3) Like the above (2), but adapted themselves under the Antarctic condition and possibly can survive henceforth.

4) Fungi contaminated during the carrying of the materials to the laboratory after the collection.

When above categories are introduced in the case of the present members, Chrysosporium pannorum can be included in (3) and Blodgettia borneti will be in (1) though it is nothing but the speculation. Other two species can hardly be included in any of these groups.

Further experiments on the Antarctic fungi are being carried out.

The writer is indebted to Dr. KoBayasI, Nat. Sci. Mus., for his valuable suggestions. I also wish to express my gratitude to Dr. $\mathbb{H}$. FukUSHIMA, Yokohama Municipal Univ., for giving the opportunity to examine these precious collections and to Dr. J. W. CARMICIAEL for his suggestions on Chrysosporium.

\section{LTIPERATUE}

BIsby, G. R. 1944. Notes on British Hyphomycetes. Trans. Brit. Mycol. Soc. 27: 101-112.

Subramanian, C. V. 1954. Fungi Imperfecti from Madras-VI. Jour. Indian Bot. Soc. 33: 36-42. 


\section{BIOLOGICAL RESULTS}

$\mathrm{OF}$

\section{THE JAPANESE ANTARCTIC RESEARCH EXPEDITION}

1. Tanita, Senji: Sponges. $8 \mathrm{pp}$.

May 1959

2. NAKASEKo, Kojiro: On Superfamily Liosphaericae (Radiolaria) from sediments in the sea near Antarctica (On Radiolaria from sediments in the sea near Antarctica. Part 1). 13 pp., 3 pls.

May 1959

3. Hirano, Minoru: Notes on some algae from the Antarctic collected by the Japanese Antarctic Research Expedition. 13 pp., 3 pls.

May 1959

4. Hatai, Kotora: A new rhynchonellid (Brachiopoda) from Antarctica. 7 pp.

May 1959

5. TokiokA, Takasi: Amaroucium erythraeum Michaelsen, a compound ascidian from the Cape Province. 6 pp.

May 1959

6. YosII, Riozo: Collembolan fauna of the Cape Province, with special reference to the genus Seira Lubbock. 24 pp.

June 1959

7. Gamô, Sigeo: On a cumacean Crustacea (Diastylis corniculatus Hale) obtained by the Second Japanese Antarctic Research Expedition (1957-58). 7 pp.

October 1959

8. Utinomr, Huzio: Pycnogonida of the Japanese Antarctic Research Expeditions 1956-1958. $12 \mathrm{pp}$.

December 1959

9. Matsubara, Kiyomatsu and Imai, Tamotsu: Fishes. 7 pp., 1 pl. December 1959

10. Tanaka, Otohiko: Pelagic Copepoda. 95 pp., 40 pls.

March 1960

11. Uchio, Takayasu: Planktonic Foraminifera of the Antarctic Ocean. 9 pp., 1 pl.

May 1960

12. Uchio, Takayasu: Benthonic Foraminifera of the Antarctic Ocean. 19 pp., 1 pl.

May 1960

13. Kobayasi, Yosio: An imperfect lichen found in the Antarctica. 7 pp. March 1961

14. Tubaki, Keisuke: On some fungi isolated from the Antarctic materials. 9 pp.

March 1961 